\title{
34. ALTERED ROCKS FROM DEEP SEA DRILLING PROJECT LEG 59
}

\author{
Andrew Hajash, Department of Geology, Texas A\&M University, College Station, Texas
}

A total of 13 samples from Holes 447A, 448, 448A, 450 , and 451 were studied chemically and mineralogically in order to determine if the samples had been affected substantially by high-temperature interaction with sea water, low-temperature alteration, or both. If high-temperature alteration dominated, one would expect a net addition of $\mathrm{Na}$ and $\mathrm{Mg}$ to the rock and loss of $\mathrm{Fe}, \mathrm{Mn}, \mathrm{Ca}, \mathrm{K}$, and $\mathrm{Si}$ (Tomasson and Kristamannsdottir, 1972; Hart, 1973; Humphris, 1975; Humphris and Thompson, 1978; Bischoff and Dickson 1975; Hajash, 1975; Mottl, 1978). If low-temperature alteration dominated, net addition of $\mathrm{K}$ and loss of $\mathrm{Ca}, \mathrm{Mg}$, and $\mathrm{Si}$ from the rock would result (Hart, 1970; Melson and Thompson, 1973; Thompson, 1973; Scott and Hajash, 1976). The clearest contrast between lowtemperature and high-temperature alteration is shown by $\mathrm{Mg}$ and $\mathrm{K}$ exchange trends. In most cases, however, the chemical data from these samples are inconclusive because (1) the initial, unweathered parent is not well characterized, (2) the samples are diverse in nature, including volcanic breccias, tuffs, and basaltic clasts, and (3) the direction and extent of chemical exchange vary considerably as a function of temperature (e.g., Scott and Hajash, 1976). In addition, it is quite likely that many of the samples have both high- and low-temperature alteration histories.

Results of major-element chemical analysis of the altered rocks are presented in Table 1 together with the average compositions of fresh basaltic glasses from Holes 448A (Scott, this volume) and 447A (Mattey et al., this volume) for comparison of elemental exchange trends. In Hole $447 \mathrm{~A}$, the only samples analyzed were

Table 1. Whole-rock chemical data from altered samples.

\begin{tabular}{|c|c|c|c|c|c|c|c|c|c|}
\hline $\begin{array}{c}\text { Sample } \\
\text { (intervals in } \mathrm{cm} \text { ) }\end{array}$ & $\mathrm{Na}_{2} \mathrm{O}$ & $\mathrm{K}_{2} \mathrm{O}$ & $\mathrm{CaO}$ & $\mathrm{MgO}$ & $\mathrm{FeO}^{\mathrm{b}}$ & $\mathrm{MnO}$ & $\begin{array}{c}\mathrm{Cu} \\
(\mathrm{ppm})\end{array}$ & $\mathrm{SiO}_{2}$ & $\mathrm{~A}_{2} \mathrm{O}_{3}$ \\
\hline 447A Fresh Glass & 2.10 & 0.02 & 12.14 & 8.16 & 9.2 & 0.12 & - & 50.60 & 15.6 \\
\hline $447 \mathrm{~A}-29-1(81-84)$ & 2.31 & 2.13 & 17.24 & 3.77 & 5.20 & 0.10 & 55 & 27.83 & 11.65 \\
\hline $447 \mathrm{~A}-36-3(12-19)$ & 1.60 & 0.72 & 14.23 & 9.91 & 3.71 & 0.12 & 74 & 28.28 & 6.38 \\
\hline $447 \mathrm{~A}-36-3(12-19)^{\mathrm{a}}$ & 1.69 & 2.57 & 0.99 & 5.83 & 11.03 & 0.12 & 156 & 38.54 & 13.29 \\
\hline 448A Fresh Glass & 2.44 & 0.43 & 8.29 & 3.78 & 13.08 & $=$ & $=$ & 53.95 & 13.40 \\
\hline$\overline{448} \cdot 50-3(111-116)$ & 2.58 & 0.91 & 7.70 & 5.05 & 10.45 & 0.17 & 83 & 47.81 & 14.85 \\
\hline $448 \mathrm{~A}-36-3(61-69)$ & 2.58 & 0.98 & 1.85 & 6.16 & 9.75 & 0.18 & 130 & 44.87 & 10.64 \\
\hline $448 A-44-1(67-71)$ & 4.12 & 0.12 & 3.71 & 5.63 & 11.46 & 0.22 & 152 & 46.31 & 12.08 \\
\hline $450-36-3(25-31)$ & 2.67 & 0.22 & 10.78 & 5.94 & 8.22 & 0.17 & 52 & 48.32 & 15.33 \\
\hline $450-36-3(81-86)$ & 2.74 & 0.38 & 10.25 & 5.82 & 7.78 & 0.14 & 73 & 50.40 & 15.61 \\
\hline $450-36-3(81-86)^{\mathrm{a}}$ & 0.75 & 0.85 & 25.45 & 5.03 & 3.81 & 0.14 & 199 & - & 4.08 \\
\hline $450-36-3(97-100)$ & 2.58 & 0.32 & 10.62 & 5.98 & 7.35 & 0.15 & 60 & 47.89 & 15.26 \\
\hline $450-36-3(104-107)$ & 2.58 & 0.66 & 10.02 & 5.12 & 9.32 & 0.15 & 63 & 44.77 & 15.13 \\
\hline $451-45-1(45-47)$ & 2.13 & 0.19 & 11.10 & 2.82 & 6.95 & 0.09 & 97 & 45,44 & 22.08 \\
\hline-121$)$ & 2.3 & 0.59 & 10.07 & 4.0 & 6.11 & 0.09 & 114 & 43.21 & 20.31 \\
\hline $451-66-1(9-13)$ & 2.53 & 1.07 & 7.23 & 3.4 & 7.17 & 0.11 & 130 & 45.25 & 17.22 \\
\hline $451-92-1(25-99)$ & 2.14 & 0.82 & 11.26 & 4.03 & 7.99 & 0.14 & 67 & 46.02 & 18.53 \\
\hline
\end{tabular}

volcanic breccias with considerable calcite matrix $(\sim 30 \%)$. Consequently, comparing the whole-rock compositions of these calcite-rich breccias to the fresh glass does not give meaningful information on the chemical exchange trends. However, the rocks from Holes 448, 448A, 450, and 451 appear more suitable because they are basalt fragments, tuffs or breccias without substantial calcite. Comparing these rocks to the fresh basalts results in the following observations:

1) $\mathrm{FeO}$ (total iron) concentrations in the altered materials are, in all cases, less than that in the fresh basalt.

2) In most cases, $\mathrm{K}_{2} \mathrm{O}$ concentrations are higher in the altered rocks than in the fresh basalt.

3) $\mathrm{MgO}$ is generally enriched in the altered rocks, but there are two exceptions (samples 451-45-1 and 45166-1).

4) $\mathrm{Na}_{2} \mathrm{O}$ and $\mathrm{CaO}$ abundances generally do not show predictable trends with respect to the composition of the fresh basalt.

The iron and magnesium trends are consistent with hydrothermal metamorphism, but the potassium data are indicative of low-temperature alteration. Consequently, the generalized chemical data do not show unequivocally whether high- or low-temperature processes dominate.

Strong evidence for hydrothermal metamorphism is observed only in Hole 448A. Compared to fresh basalt from the upper part of the same hole, Sample 448A-44-1 $(67-71 \mathrm{~cm})$ is enriched in $\mathrm{Na}_{2} \mathrm{O}$ and $\mathrm{MgO}$ and depleted in $\mathrm{K}_{2} \mathrm{O}, \mathrm{CaO}$, and $\mathrm{FeO}$. All of these exchange trends imply high-temperature alteration and are consistent with the oxygen-isotope data of Aldrich et al. (this volume), which indicated that a temperature of $170^{\circ} \mathrm{C}$ was reached somewhat deeper in the hole-Sample 448A 57-2 (90-95). In addition, analcite and pyrite were identified in the sample by X-ray diffraction. Other samples such as the four from Sections 450-36-3 and the one from Section 451-45-1 $(45-47 \mathrm{~cm})$ have compositions that are generally consistent with hydrothermal metamorphism, but a low-temperature "overprint" is observed (e.g., enriched in $\mathrm{K}_{2} \mathrm{O}$ and $\mathrm{CaO}$ ).

Secondary minerals are mostly brown to green smectite and $\mathrm{Fe}$-oxides (which replace olivine), green smectites (which replace altered glass fragments in the tuffs and breccias), and calcite and zeolites, which fill vesicles and serve as vein material (see Table 2). Calcite and fibrous mordenite coexist in Sample 451-92-1 (25-99 $\mathrm{cm})$ as vein material.

In conclusion, assuming that the unaltered equivalents of these rocks are accurately represented by the 
Table 2. Rock descriptions, Holes 447A, 448, 448A, 450, 451.

447A-29-1, (81-84 cm)

Breccia with $3-4 \mathrm{~cm}$-long volcanic rock fragments; the matrix is dominantly calcite and brownish-orange clay. Olivine (?) in rock fragments is replaced by rusty brown aggregate of smectite and $\mathrm{Fe}$ oxides.

447A-36-3 (12-19 cm)

Volcanic glass breccia, $0.3-3 \mathrm{~cm}$ glass clasts partially altered to green smectite. Some of the larger fragments appear unaltered in the interior; the matrix consists of coarse white calcite with red specks of iron oxides (hematite?) distributed nonuniformly.

448-50-3 (111-116 cm)

Dark gray slightly vesicular basalt with irregularly shaped cavities partially filled with calcite. This sample is a portion of a clast from a volcanic breccia.

448A-36-3 (61-69 cm)

Black to greenish-black volcanic breccia with $0.5-1-\mathrm{cm}$ angular to subangular vesicular clasts; the matrix is predominantly green smectite; phillipsite and calcite are scattered throughout the rock along grain boundaries and in $\sim 1$-mm-diameter vugs.

448A-44-1 (67-71 cm)

Volcanic breccia, dark gray to black with gray to grayish-blue smectite matrix; fine-grained pyrite occurs with analcite in altered clasts.

450-36-3 $(25-31 \mathrm{~cm})$

Dark reddish-gray, fine vitric tuff contains a 2 -mm-wide vein of calcite, smectite, and hematite.

450-36-3 (81-86 cm)

Dark gray fine vitric tuff (primary olivine appears to be replaced by brown smectite and $\mathrm{Fe}$ oxides), contains light green clasts of calcareous clay up to $2-3 \mathrm{~cm}$ across.

450-35-3 (97-100 cm)

Same as above.

450-36-3 (104-107 cm)

Same as above.

$451-45-1(45-47 \mathrm{~cm})$

Dark gray to greenish-gray volcanic breccia with one large cavity ( $\sim 2 \mathrm{~cm}$ diameter) lined with clear euhedral phillipsite crystals; basaltic clasts are $1-5 \mathrm{~mm}$ in diameter.

$451-45-1(117-121 \mathrm{~cm})$

Portion of a phyric black vesicular basalt clast with a $7 \mathrm{~mm}-\times-30$ mm irregularly shaped vein made up primarily of chalcedony with discontinuous calcite along the margins; vesicles are lined with dark greenish-brown smectite and fine-grained calcite.

451-66-1 (9-13 cm)

Medium gray vitric tuff made up of coarse to fine sand-size grains; plagioclase and smectite identified by $x$-ray diffraction.

451-92-1 (25-99 cm)

Gray vesicular basalt with calcite and fibrous mordenite in a $\sim 5$-mm-thick vein and filling vesicles. "fresh" basalt, the data are generally consistent with high-temperature alteration followed by some degree of alteration at low temperatures. However, because the direction and extent of chemical exchange vary as a function of temperature, extreme care should be exercised when using major-element data alone to distinguish between high- and low-temperature alteration processes. For example, elements such as $\mathrm{Fe}$ and $\mathrm{Ca}$ leached from rocks at depth by a hydrothermal fluid may be precipitated at shallower depths where temperature is lower, but the whole process is nevertheless one of high-temperature alteration.

\section{ACKNOWLEDGMENTS}

Appreciation is extended to Dr. Robert B. Scott and Mr. George Bolger, Geology Department, Texas A\&M University, for reviewing this report.

\section{REFERENCES}

Bischoff, J. L., and Dickson, F. W., 1975. Seawater-basalt interaction at $200^{\circ} \mathrm{C}$ and 500 bars: implications for origin of sea-floor heavy-metal deposits and regulation of seawater chemistry. Earth Planet. Sci. Lett., 25:385-387.

Hajash, A. 1975. Hydrothermal processes along mid-ocean ridges: an experimental investigation. Contrib. Mineral. Petrol., 53:205-226.

Hart, R., 1970. Chemical exchange between seawater and deep ocean basalts. Earth Planet. Sci. Lett., 9:269-279.

Hart, S. R., 1973. A model for chemical exchange in the basaltseawater system of oceanic layer II. Can. J. Earth Sci., 10:799816.

Humphris, S. E., 1975. Elemental fluxes during hydrothermal alteration of basalts. EOS Am. Geophys. Union Trans., 56:469. (Abstract)

Humphris, S. E., and Thompson, G., 1978. Hydrothermal alteration of oceanic basalts by seawater. Geochim. Cosmochim. Acta, 42:107-125.

Melson, W. G., and Thompson, G., 1973. Glassy abyssal basalts, Atlantic sea floor near St. Paul's Rocks: petrography and composition of secondary clay minerals. Geol. Soc. Am. Bull., 84:703-716.

Mottl, M., 1978. Chemical exchange during hydrothermal alteration of basalt by seawater-I. Experimental results for major and minor components of seawater. Geochim. Cosmochim. Acta, 42:1103-1115.

Scott, R. B., and Hajash, A., 1976. Initial submarine alteration of basaltic pillow lavas: a microprobe study. Am. J. Sci., 276:480501.

Thompson, G., 1973. A geochemical study of the low-temperature interaction of seawater and oceanic igneous rocks. EOS $\mathrm{Am}$. Geophys. Union Trans., 54:1015-1019.

Tomasson, J., and Kristmannsdottir, H., 1972. High temperature alteration and thermal brines, Reykjanes, Iceland. Contrib. Mineral. Petrol., 36:123-134. 